\title{
A new species of Poptella (Characiformes: Characidae: Stethaprioninae) from the Rio Juma, Rio Madeira basin, Brazil
}

\author{
James R. Garcia-Ayala ${ }^{1}$ and Ricardo C. Benine ${ }^{2}$
}

A new species of Poptella is described from the Rio Juma, a tributary of the lower Rio Aripuanã, Rio Madeira basin, Amazonas, Brazil. The new species is distinguished from all congeners, except $P$. brevispina, by having a lower number of scale rows between the lateral line and dorsal-fin origin $(7 v s .8-10)$. The new species can be readily distinguished from $P$. brevispina by the lower number of branched dorsal-fin rays $(9 \mathrm{vs} .10)$. This is the first description of a new species of Poptella since the revisionary study of the Stethaprioninae, published 30 years ago.

Keywords: Amazon, Biodiversity, Freshwater fish, Stethaprionini, Taxonomy.

Uma nova espécie de Poptella é descrita do Rio Juma, tributário do baixo Rio Aripuanã, bacia do rio Madeira, Amazonas, Brasil. A nova espécie é distinguida de todas suas congêneres, exceto P. brevispina, por apresentar menor número de séries de escamas entre a linha lateral e origem da nadadeira dorsal (7vs. 8-10). A nova espécie pode ser facilmente diferenciada de P. brevispina pelo menor número de raios ramificados na nadadeira dorsal ( $9 v s .10)$. Esta é a primeira descrição de uma nova espécie de Poptella desde a última revisão taxonômica de Stethaprioninae, publicada há trinta anos.

Palavras-chave: Amazônia, Biodiversidade, Peixes de água doce, Stethaprionini, Taxonomia.

\section{Introduction}

The subfamily Stethaprioninae was first proposed by Eigenmann (1907). It is morphologically defined by the presence of a bony, anteriorly directed spine, preceding the first dorsal-fin ray, and by the presence of very small, thin anal-fin hooks facing in all directions on mature males (Eigenmann, 1907; Reis, 1989). Recently, Mirande (2018) proposed a new phylogenetic classification based on morphological and molecular characters. This author expanded Stethaprioninae and divided it into four tribes: Stethaprionini Eigenmann, 1907, Grundulini Fowler, 1958, Gymnocharacini Eigenmann, 1909, and Rhoadsiini Fowler, 1911. Mirande also expanded the Stethaprionini to comprise, along with Brachychalcinus, Orthospinus, Poptella, and Stethaprion (original genera of the Stethaprioninae Eigenmann, 1907; Reis, 1989), species of Aphyodite, Bryttanichthys, Bryconella, Ectretopterus, Gymnocorymbus, Hasemania, Hemigrammus, Hyphessobrycon, Jupiaba, Moenkhausia, Petitella, Pristella, and Stichonodon.

Poptella is widely distributed in all the major cis-Andean tropical South America river drainages, and small rivers flowing into the Atlantic from South America, between the
Río Orinoco and the Rio Parnaíba, except the upper Rio Paraná, Rio Uruguay and Rio São Francisco (Reis, 1989, 2003). The genus Poptella was proposed by Eigenmann (1907) to allocate Tetragonopterus compressus Günther, 1864, based on syntypes from Guyana, Suriname, and Peru. Poptella is characterized by having the anterior end of the predorsal spine rounded and ventrally concave and saddleshaped, and first anal-fin ray not expanded (Reis, 1989).

Poptella currently comprises four valid species: $P$. brevispina Reis (1989), P. compressa (Günther, 1864), P. longipinnis (Popta, 1901), and P. paraguayensis (Eigenmann, 1907). The diagnostic characters of these species rely on the number of branched dorsal-fin rays, length of predorsal spine, number of rows of scales between the lateral line and dorsal-fin origin, and degree of pigmentation on adipose fin. The Stethaprioninae Eigenmann (1907) was the subject of a systematic study (Reis, 1989) in which $P$. brevispina was the last species of Poptella to be described. After almost three decades of Reis's paper, the continuous examination of Poptella collected in various localities along the Amazon basin revealed a new species, apparently endemic to the Rio Juma, Rio Madeira system, which we formally describe herein.

${ }^{1}$ Laboratório de Biologia e Genética de Peixes, Departamento de Morfologia, Instituto de Biociências, Universidade Estadual Paulista IBB-UNESP, R. Prof. Dr. Antonio C. W. Zanin, s/n, Rubião Jr, 18618-689 Botucatu, SP, Brazil. jamesrga@hotmail.com, Dhttps://orcid. org/0000-0002-5810-7025 (corresponding author).

${ }^{2}$ Laboratório de Ictiologia, Departamento de Zoologia, Campus de Botucatu, Universidade Estadual Paulista - IBB-UNESP, R. Prof. Dr. Antonio C. W. Zanin, s/n, Rubião Jr, 18618-689 Botucatu, SP, Brazil. ricardo.benine@unesp.br, ○https://orcid.org/0000-0002-0892-9768 


\section{Material and Methods}

Counts and measurements follow Sidlauskas et al. (2011) and Fink, Weitzman (1974), except for the number of scale rows between lateral line and midventral scale series, which were counted at the vertical just ahead of the pelvicfin insertion, and head depth, which was measured at the vertical through the tip of supraoccipital spine; the predorsal spine length is added, measured as the greatest length along its longitudinal axis, taken point to point. The number of scale rows between dorsal-fin origin and lateral line was counted in all paratypes, considering their diagnostic nature. Measurements were taken point to point with a digital caliper (precision of $0.1 \mathrm{~mm}$ ) on the left side of specimens. Values between parentheses indicate the number of specimens with a particular count and the asterisk indicates values of the holotype. For osteological observations, cleared and stained (c\&s) specimens were prepared according to Taylor, Van Dyke (1985). Radiographs were taken using the X-ray system Faxitron LX60 DC12 at LIRP (FFCLRP-USP). Vertebral counts included the four vertebrae of the Weberian apparatus and the terminal centrum counted as one single element, and were taken from two c\&s specimens. Color description in life was based on field photographs of one freshly collected specimen. Measurements are presented as proportions of standard length, except for subunits of the head, which are given as proportions of head length. Specimens examined herein belong to the following institutions: Instituto Nacional de Pesquisas da Amazônia, Manaus (INPA), Laboratório de Biologia e Genética de Peixes, Instituto de Biociências, Universidade Estadual Paulista, Botucatu (LBP), Museo de Historia Natural de la Universidad Nacional Mayor de San Marcos, Lima (MUSM), Museu Paraense Emílio Goeldi, Belém (MPEG), Museu de Zoologia da Universidade de São Paulo, São Paulo (MZUSP) and Royal Ontario Museum, Toronto (ROM).

\section{Results}

\section{Poptella actenolepis, new species}

urn:1sid:zoobank.org:act:B6B8028A-CD25-426C-939997E2A371A980

Figs. 1-3, Tab. 1

Poptella compressa. -Pastana, Ohara, 2016:392 [Rio Juma, tributaries of Rio Aripuanã basin; ecological notes]. -Ohara et al., 2017:8 [Rio Juma, tributaries of Rio Aripuanã basin; ecological notes]. -Garcia-Ayala et al., 2017:571 [Rio Juma, tributaries of Rio Aripuanã basin; comparative material].

Holotype. MZUSP 124423, $71.9 \mathrm{~mm}$ SL, radiographed, Brazil, Amazonas, Apuí, Rio Juma, tributary of the Rio Aripuanã, Rio Madeira basin, igarapé Mutum, nearby the bridge on road BR 230 between Vicinal Brasília and Nova Esperança, $07^{\circ} 14^{\prime} 56^{\prime \prime}$ S 59 $58^{\prime} 42.744^{\prime \prime W}, 8$ Oct 2016, O. Oyakawa, W. M. Ohara, T. Teixeira \& M. Pastana.

Paratypes. All from Brazil. MZUSP 117635, 49, 25.9-36.5, 4 c\&s 31.2-34.5 mm SL, Amazonas, Apuí, Rio Juma, upstream cachoeira do Paredão, tributary of Rio Aripuanã, Rio Madeira basin, 0749'22"S 6051'06”'W, 24 Jun 2015, W. M. Ohara \& V. Abraão. MZUSP 117586, 26 (15 measured, 17.4-39.9 mm SL), Amazonas, Apuí, Rio Juma, tributary of Rio Aripuanã, Rio Madeira basin, $07^{\circ} 12^{\prime} 44.64$ 'S 59 $55^{\prime} 19.74$ 'W, 24 Jun 2015, W. M. Ohara \& V. Abraão. MZUSP 122982, 27 (5 measured, 55.1-72.3 mm SL), radiographed, 2 c\&s 61.5-63 $\mathrm{mm}$ SL, same data as holotype.

Diagnosis. Poptella actenolepis can be distinguished from all congeners, except from $P$. brevispina, by having a lower number of scale rows between lateral line and dorsal-fin origin (7 vs. 8-10). It can be distinguished from P. brevispina and $P$. longipinnis by having a lower number of branched dorsal-fin rays (9 vs. 10). Poptella actenolepis can also be differentiated from $P$. longipinnis by having the first rays of the dorsal and anal fin darker and much longer than the following rays (vs. first dorsal and anal fin rays slightly longer than the following rays). The new species differs from $P$. paraguayensis by having a lower number of branched anal-fin rays (27-29 vs. 30-35) and a comparatively shorter predorsal spine (2.8-4.3 vs. 4.7-6.4\% mm SL).

Description. Morphometric data summarized in Tab. 1. Largest specimen examined $72.4 \mathrm{~mm}$ SL. Greatest body depth at dorsal-fin origin. Dorsal profile slightly convex between tip of snout and vertical through middle of orbit; slightly concave from this point to end of occipital process, convex from tip of occipital process to dorsal-fin origin. Dorsal-fin base posteroventrally slanted. Profile straight or slightly convex from posterior terminus of dorsal-fin base to end of adipose fin. Caudal peduncle profile slightly concave both dorsally and ventrally. Ventral profile of head and body convex from tip of dentary to anal-fin insertion. Body profile along anal-fin base straight and posterodorsally slanted. Prepelvic region compressed with a median keel.

Mouth terminal. Maxilla reaching vertical passing through anterior margin of pupil; its posterior end not extending beyond third infraorbital. Premaxillary teeth in two rows. Outer row with $4 *(40)$ or $5(3)$ teeth with three cusps. Inner row with 5(43) teeth with five cusps. Maxilla with 1(11) or $2 *(32)$ teeth with three cusps or conical. Dentary with five pentacuspidate teeth, usually central cusp longest, followed by a series of 7 to 9 small conical teeth (Fig. 2).

Dorsal-fin rays iii,9*(43). First dorsal-fin element modified into a small predorsal spine, with a rounded tip in lateral view and slightly curved in dorsal view, with two projections postero-ventrally resembling a saddle (Fig. 3). First unbranched dorsal-fin ray shorter than second. Dorsalfin origin anterior to vertical through middle of standard 
length. Adipose fin present. Anal-fin rays iv,27(4); v,27(4); iv,28*(20); v,28(2); iv,29(10) or v,29(3). Anterior unbranched anal-fin rays slightly longer than following rays. Anal-fin origin at vertical through two scales posterior to last branched dorsal-fin ray. Pectoral-fin rays i,10(26) or i,11*(17). Tip of pectoral-fin extends beyond midlength of adpressed pelvicfin. Pelvic-fin rays i,6(1) or $7^{*}(42)$. Tip of adpressed pelvic fin reaching second anal-fin ray. Pelvic-fin origin anterior to middle of standard length. Caudal fin $\mathrm{i}, 17, \mathrm{i}^{*}(3)$, rarely $15(2)$ branched rays. Dorsal procurrent caudal-fin rays 12(5); ventral procurrent caudal-fin rays $9 *(2)$ or 10(3). Caudal-fin forked, lobes somewhat pointed and similar in size.
Cycloid scales with six to nine parallel radii. Lateral line complete with $34 *(34)$ or $35(10)$ perforated scales; lateral line deflected downward. Predorsal scales 5(8), 6(25) or $7(10)^{*}$. Scale rows between dorsal-fin origin and lateral line $7(105)$. Scale rows between lateral line and pelvic-fin origin $8(43)$. Scale rows around caudal peduncle 13(13) or $14 *(30)$. Single series of 10 to 13 scales covering base of anterior anal-fin rays. Small scales covering proximal twothirds of caudal-fin lobes.

First gill arch with $13 *(30)$ or $14(13)$ rakers on lower limb and $9(6)$ or $10^{*}(37)$ rakers on upper limb. Total vertebrae $30 *(5)$. Supraneurals $3 *(5)$ (Fig. 1b).

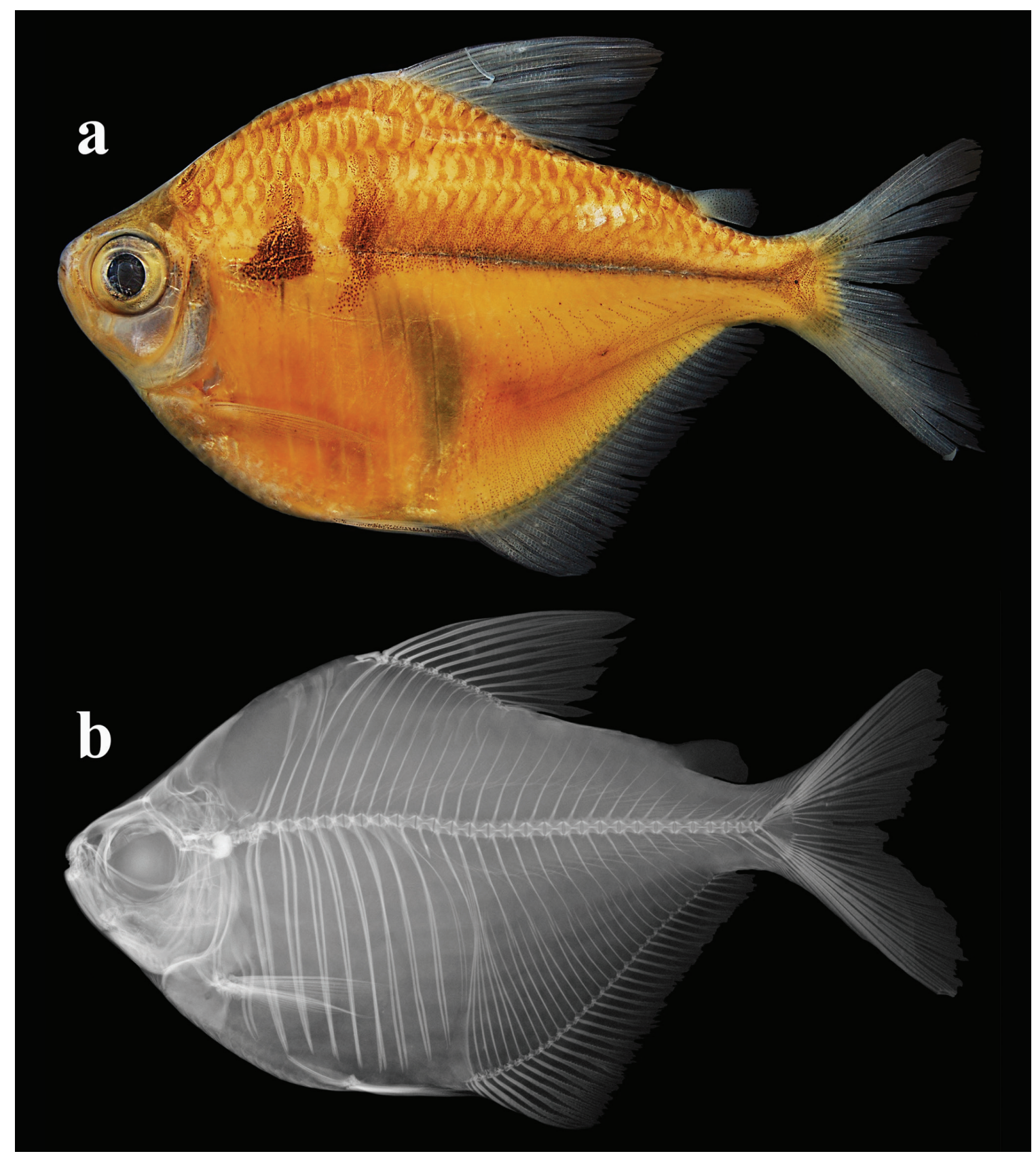

Fig. 1. a. Poptella actenolepis, holotype, MZUSP 124423, 71.9 mm SL, Brazil, Amazonas, Apuí, Rio Juma, Rio Madeira basin; b. radiograph of the holotype. 
Tab. 1. Morphometric data of Poptella actenolepis. Range includes holotype. SD = Standard deviation.

\begin{tabular}{|c|c|c|c|c|c|}
\hline & Holotype & $\mathrm{N}$ & Range & Mean & SD \\
\hline Standard length (mm) & 71.9 & 43 & $18.3-72.4$ & 45.4 & - \\
\hline \multicolumn{6}{|c|}{ Percentage of standard length } \\
\hline Snout to dorsal-fin origin & 51.4 & 43 & $50.1-57.7$ & 53.5 & 0.8 \\
\hline Snout to adipose-fin origin & 86.3 & 43 & $81.2-91.1$ & 86.6 & 0.8 \\
\hline Snout to anal-fin origin & 67.1 & 43 & $64.9-74.9$ & 69.3 & 1.1 \\
\hline Snout to pelvic-fin origin & 55.2 & 43 & $50.9-57.3$ & 54.2 & 1.7 \\
\hline Snout to pectoral-fin origin & 30.2 & 43 & $29.7-34.6$ & 31.9 & 0.7 \\
\hline Dorsal-fin origin to pectoral-fin origin & 47.9 & 43 & $34.7-51.8$ & 44.5 & 1 \\
\hline Dorsal-fin origin to pelvic-fin origin & 57.9 & 43 & $36.9-61.1$ & 49.6 & 1.6 \\
\hline Dorsal-fin origin to anal-fin origin & 57.6 & 43 & $39.1-63.3$ & 51.1 & 1.2 \\
\hline Dorsal-fin origin to anal-fin end & 54.4 & 43 & $45.8-57.4$ & 51.8 & 1 \\
\hline Dorsal-fin origin to hypural joint & 58.3 & 43 & $51.7-59.7$ & 55.7 & 0.9 \\
\hline Dorsal-fin origin to adipose-fin origin & 40.3 & 43 & $32.9-44$ & 38.7 & 0.7 \\
\hline Length of dorsal-fin base & 17.2 & 43 & $12.2-19.1$ & 15.9 & 0.7 \\
\hline Dorsal-fin end to pelvic-fin origin & 53.4 & 43 & $34.7-56.4$ & 45.7 & 1 \\
\hline Dorsal-fin end to adipose-fin origin & 22.5 & 43 & $19.4-25.9$ & 22.7 & 0.7 \\
\hline Dorsal-fin end to anal-fin origin & 49.1 & 43 & $35.4-54.1$ & 44.4 & 1 \\
\hline Dorsal-fin end to anal-fin end & 33.2 & 43 & $27.1-39.4$ & 34.15 & 0.6 \\
\hline Adipose-fin origin to anal-fin origin & 50 & 43 & $34.8-52.5$ & 44.4 & 1.1 \\
\hline Adipose-fin origin to anal-fin end & 17.1 & 43 & $11.5-18.1$ & 14.8 & 0.5 \\
\hline Adipose-fin origin to hypural joint & 18.1 & 43 & $13.8-18.7$ & 16.1 & 1.1 \\
\hline Length of anal-fin base & 42.1 & 43 & $29.1-43.6$ & 36.8 & 1.1 \\
\hline Predorsal spine & 3.9 & 43 & $2.8-4.3$ & 3.6 & 0.2 \\
\hline Anal-fin origin to hypural joint & 8.6 & 43 & $8.2-13.8$ & 10.2 & 0.9 \\
\hline Pectoral-fin length & 23.5 & 43 & $18.4-28.3$ & 23.3 & 1.2 \\
\hline Pelvic-fin length & 17.6 & 43 & $12.3-20.2$ & 16.1 & 1.1 \\
\hline Dorsal-fin length & 31.7 & 43 & $28.2-40.7$ & 34.3 & 0.9 \\
\hline Anal-fin length & 22.4 & 43 & $14.2-26.6$ & 22.8 & 1.7 \\
\hline Distance from eye to dorsal-fin origin & 41.1 & 43 & $32.1-41.1$ & 36.7 & 0.6 \\
\hline Pelvic-fin origin to anal-fin origin & 16.1 & 43 & $10.8-22.6$ & 15.8 & 0.8 \\
\hline Pelvic-fin origin to adipose-fin origin & 59.7 & 43 & $43.1-65.3$ & 53.5 & 1.2 \\
\hline Pelvic-fin origin to hypural joint & 64.5 & 43 & $51-68.4$ & 60.1 & 0.9 \\
\hline Pelvic-fin origin to pectoral-fin insertion & 23.8 & 43 & $15.3-24.5$ & 20.5 & 1.1 \\
\hline Greatest body depth & 56 & 43 & $38.6-59.9$ & 48.9 & 1.2 \\
\hline Greatest body width & 12.6 & 43 & $4.3-13.7$ & 8.7 & 0.5 \\
\hline Caudal-peduncle depth & 9.5 & 43 & 7.7-11.7 & 9.6 & 0.8 \\
\hline Head depth & 49.4 & 43 & $31.8-49.7$ & 41.9 & 1 \\
\hline Snout to supraoccipital crest & 31.3 & 43 & $30.7-36.3$ & 33.4 & 1 \\
\hline Head length & 27.8 & 43 & $23.1-32$ & 28.3 & 0.8 \\
\hline \multicolumn{6}{|c|}{ Percentage of head length } \\
\hline Preopercle length & 78.3 & 43 & $66.3-89.4$ & 77.2 & 1.7 \\
\hline Snout to anterior margin of eye & 22.6 & 43 & $19.7-28.9$ & 24.8 & 0.9 \\
\hline Snout depth & 11.7 & 43 & $11.1-22.2$ & 15.3 & 1.4 \\
\hline Jaw length & 45.2 & 43 & $41.4-54.6$ & 47.1 & 1.1 \\
\hline Eye diameter & 47.5 & 43 & $47.5-57.6$ & 52.1 & 1.3 \\
\hline Interorbital width & 36.8 & 43 & $32-46.8$ & 38.6 & 1 \\
\hline
\end{tabular}




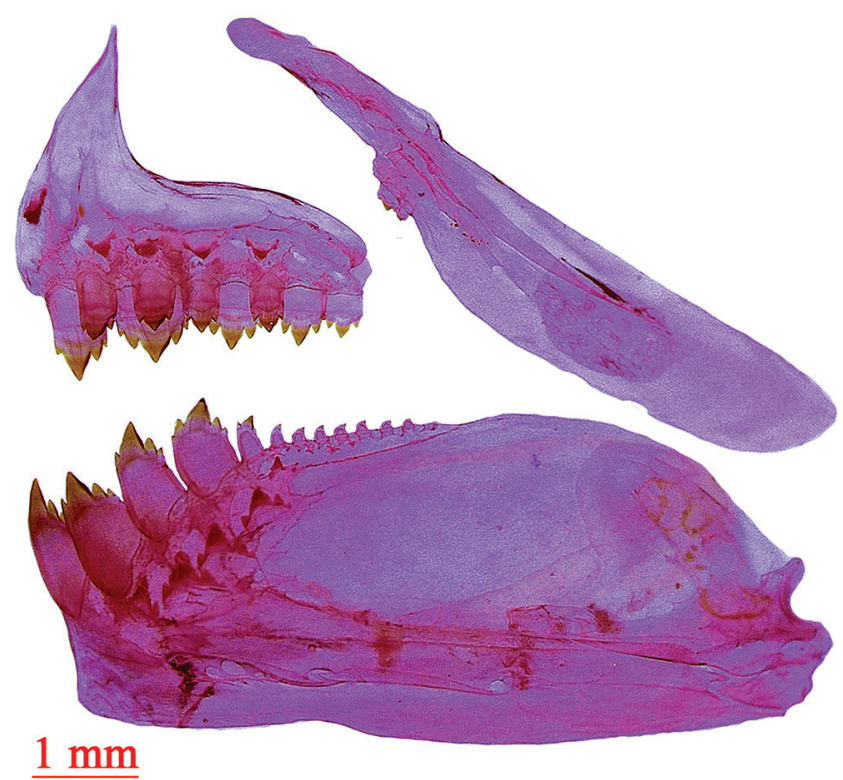

Fig. 2. Lateral view of left side of premaxilla, maxilla and dentary of Poptella actenolepis, MZUSP 122982, paratype, $63 \mathrm{~mm}$ SL.

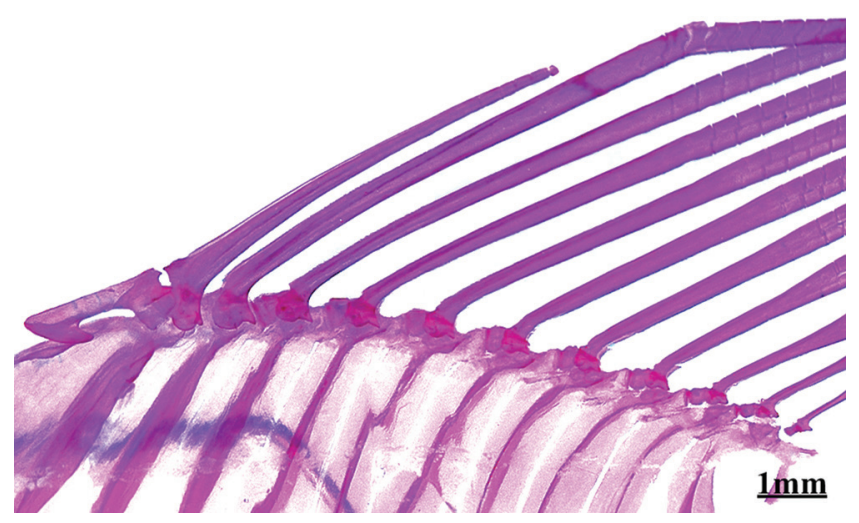

Fig. 3. Poptella actenolepis, MZUSP 122982, paratype, $61.5 \mathrm{~mm}$ SL, lateral view of left side of modified dorsal fin element.

Color in alcohol. General body color yellowish. Dorsal portion of head and body darkly pigmented. Chromatophores concentrated on snout, jaws, and dorsal portion of neurocranium. Chromatophores more densely concentrated along the entire dorsal median line. Upper half of scales slightly dark and generally delineated by black chromatophores, producing slightly crosslinked aspect. Two humeral blotches separated by a lighter area. First humeral blotch rounded, encompassing three horizontal scale series and three vertical scale series formed by dark chromatophores concentrated deeply under skin. Second humeral blotch faint, extending about two scales horizontally and two scales vertically, with dark chromatophores scarcely distributed deeply under skin, narrow longitudinal dark line running along horizontal septum, extending from humeral region to caudal peduncle. Caudal peduncle blotch absent. Pectoral fin hyaline, with chromatophores scattered throughout interradial membrane. Dorsal, pelvic and anal fins with scattered dark chromatophores, more concentrated along first rays and interradial membranes. Adipose fin with scattered dark chromatophores throughout the fin. Caudal fin with scattered dark chromatophores on posterior margins of rays and interradial membranes (Fig. 1a).

Color in life. Dorsal portion of head and body green brownish. Infraorbitals and opercular area silvery. Iris orange on upper portion, silvery ventrally, anterior and posterior portions of eye with faint silvery pigmentation. Middorsal and ventral portions of body silvery. First humeral blotch conspicuous, second humeral blotch inconspicuous. Dorsal, adipose, pelvic, and anal fins orange. Pectoral and caudal fins yellow (Fig. 4).

Sexual dimorphism. Mature males of Poptella actenolepis over $60.0 \mathrm{~mm}$ SL exhibit a series of small bony hooks on all fins. Hooks usually concentrated on postero-lateral margin of each segment of distal half of fin rays. Hooks distributed on $1^{\text {st }}$ to $7^{\text {th }}$ branched dorsal-fin rays, with one to two hooks per ray segment. Pectoral and pelvic fins with one or two hooks per ray segment, distributed from $1^{\text {st }}$ to $5^{\text {th }}$ branched fin rays. Anal fin with with one to three hooks per ray segment of most branched rays $\left(1^{\text {st }}-27^{\text {th }}\right)$, being more numerous on the first seventh branched rays. Caudal fin with one hook on per ray segment, more concentrated on middle and inferior lobe rays. Further secondary sexual dimorphisms, such as differences in standard length or sexual dichromatism, were not detected in P. actenolepis.

Geographic distribution. Poptella actenolepis is known from Rio Juma, a tributary of the lower Rio Aripuanã, Rio Madeira basin, Amazonas, Brazil (Fig. 5).

Etymology. The specific epithet "actenolepis" is from the greek akten, meaning without lot, poor; and from the greek lepis, meaning scale, in reference to the lower number of transversal scale rows of the new species. An adjective.

Conservation status. Poptella actenolepis is so far known only from the rio Juma and one of its tributaries, rio Aripuanã drainage, and its conservation status is uncertain based on the currently available data of its geographic distribution. However, considering that no imminent threats to the species were detected in the area of occurrence of the new species, we suggest that $P$. actenolepis be classified as least concern (LC) according to the International Union for Conservation of Nature categories and criteria (IUCN, 2017).

Remarks. Reis (1989) diagnosed Poptella compressa from congeners by the combination of a larger predorsal spine, ii +9 dorsal-fin rays, and hyaline adipose fin. Considering this, $P$. actenolepis can be mistaken for $P$. compress $a$, being 


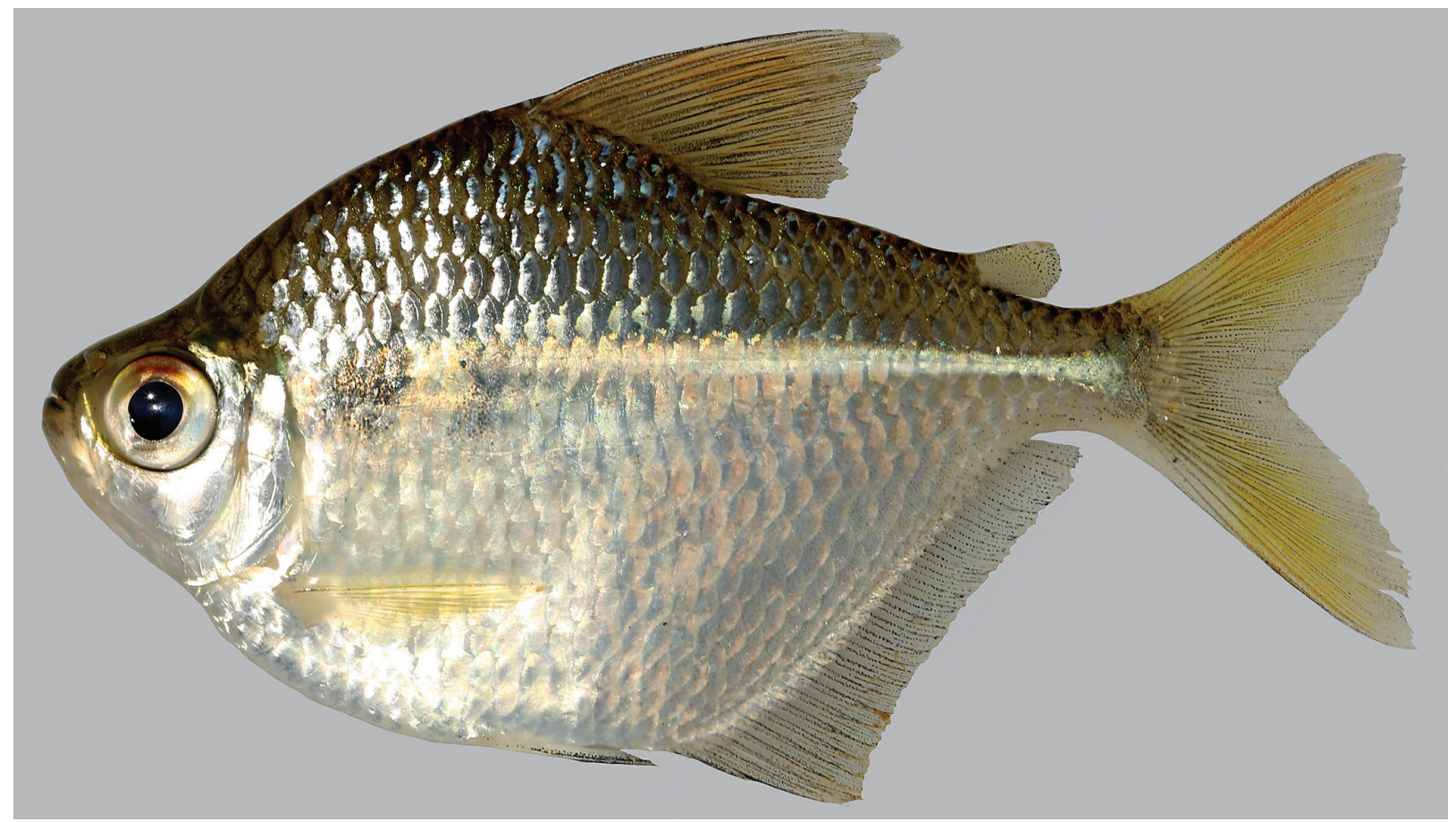

Fig. 4. Poptella actenolepis, MZUSP 122982, paratype, 55.1 mm SL, Brazil, Amazonas, Apuí, Rio Juma, Rio Madeira basin. Photo by W. Ohara.

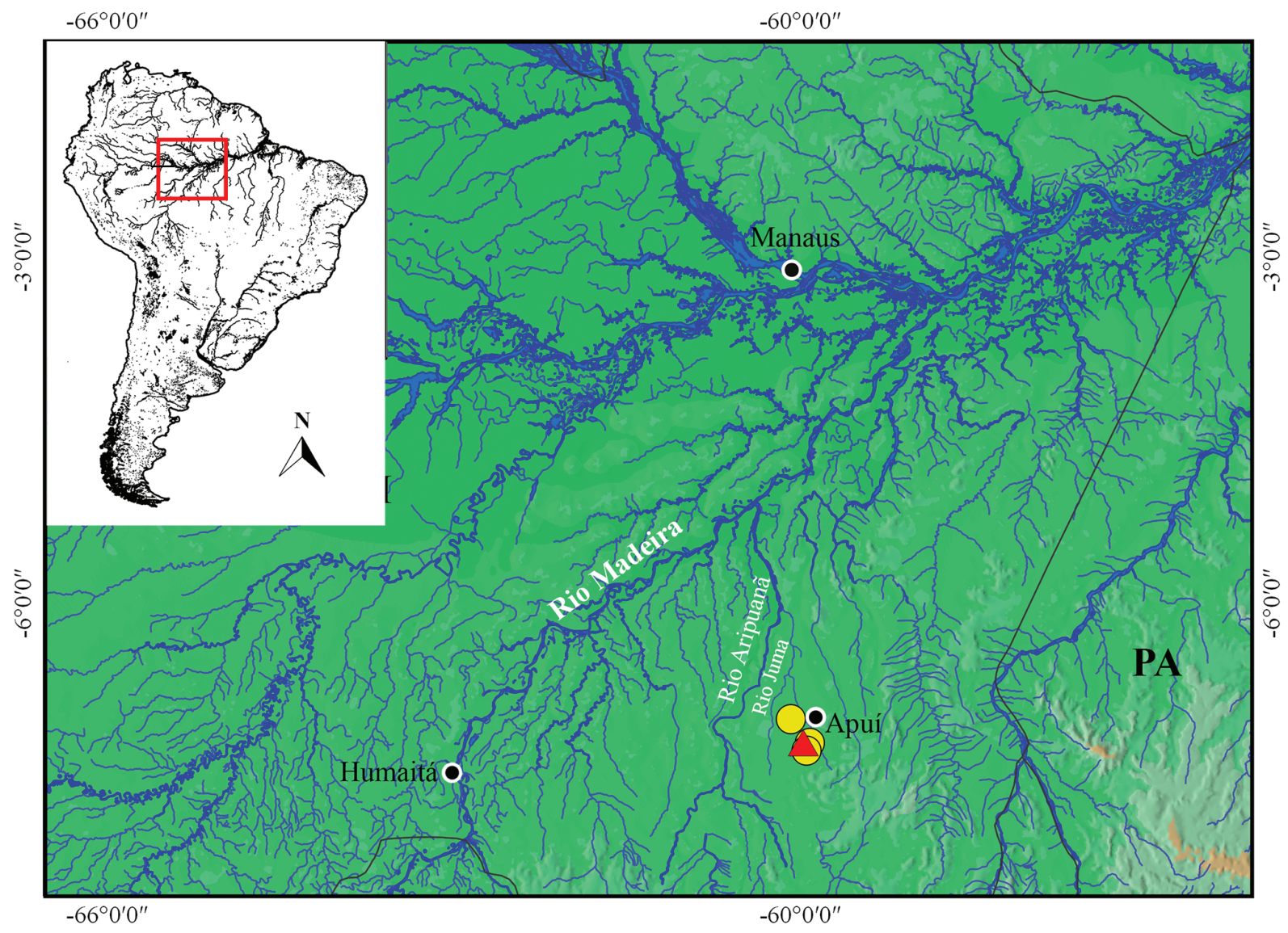

Fig. 5. Map showing the type-locality (red triangle) of Poptella actenolepis, Rio Juma, a tributary from the Rio Aripuanã, Rio Madeira basin, Brazil. Yellow circles represent paratypes. 
only differentiated by the number of longitudinal series of scales above the lateral line (7vs. 8-9, respectively). It is noteworthy that our comparative examination evidenced that 313 specimens of $P$. compressa, varying from 23.2-72.2 $\mathrm{mm}$ in SL, have, consistently, eight to nine longitudinal scale rows above the lateral line and, on the other hand, for P. actenolepis, 105 specimens, ranging from $18.3-72.5 \mathrm{~mm}$ SL, consistently have only seven longitudinal scale rows above the lateral line.

Among the valid species of Poptella, P. compressa, is widely distributed in the Amazon basin and northeastern Brazil (Reis, 1989, 2003). In the Rio Madeira, it is known to occur only in its upper portion (Rio Guaporé and Rio Jamari). Poptella actenolepis is only known from the Rio Juma, a tributary of the the highly endemic Rio Aripuanã (see Kullander, 1995; Ohara et al., 2017). Ohara et al. (2017) discussed that the fish endemism is not only characteristic to the upper portion of the Rio Aripuanã, as first discussed by Kullander (1995), but, actually, patchily distributed in its upper and middle portions. P. actenolepis, as several examples cited by Ohara et al. (2017), is only known from its type locality, and most probably restricted to this area.

Garcia-Ayala et al. (2017) discussed that small bony hooks on all fins of adult males are present in Poptella compressa, P. brevispina, P. longipinnis, and in Brachychalcinus reisi. Adult males of P. actenolepis also bear bony hooks on rays of all fins. Although the occurrence of bony hooks on all fins of mature males has been considered an uncommon characteristic in Characidae (Bertaco, Lucinda, 2006; Bertaco et al., 2007; Mirande, 2010; Camelier, Zanata, 2014), it seems to be well distributed in the Stethaprioninae (sensu Reis, 1989), as already indicated in the description of B. reisi (GarciaAyala et al., 2017).

Comparative material examined. Brachychalcinus nummus: Peru: LBP 23927, 6, 57.3-72.5 mm SL; Loreto, Rio Amazonas basin. Orthospinus franciscoensis: Brazil: LBP 8105, 15, 42.553.9 mm SL; Minas Gerais, Rio São Francisco basin. Poptella brevispina: Brazil: INPA 52824, 5, 52.6-64.1 mm SL; Pará, Rio Xingu basin. LBP 9332, 28, 54.3-88.2 mm SL; Pará, Rio Guamá. LBP 21014, 11, 29.4-44.3 mm SL; Amapá, Rio Oiapoque. Guyana: MZUSP 109124, 5 of 10, 64.1-68.2 mm SL; PotaroSiparuni, Rio Kurobromg. Poptella compressa: Brazil: INPA 1307, 2, 42.5-47.7 mm SL; Roraima, Rio Amazonas basin. LBP 16222, 7, 38.5-68.2 mm SL; Pará, Rio Tapajós basin. INPA 9193, 3, 39.4-46 mm SL; Pará, Rio Trombetas basin. INPA 5469, $1,56.9$ mm SL; Amazonas, Rio Amazonas basin. INPA 20948, 5, 41.646.7 mm SL. INPA 21758, 1, $55.1 \mathrm{~mm}$ SL. All from Rondônia, Rio Madeira basin. LBP 10825, 1, $28.1 \mathrm{~mm}$ SL; Mato Grosso, Rio Madeira basin. LBP 13730, 1, 38.9 mm SL. LBP 14115, 15, 56.7-70 mm SL. LBP 14204, 1, 52.5 mm SL. LBP 14241, 1, 44.2 mm SL. LBP 16213, 1, $39.1 \mathrm{~mm}$ SL. LBP 16222, 7, 38.5-68.2 mm SL. LBP 16228, 1, 36 mm SL. LBP 16268, 1, 50.5 mm SL. LBP 16408, 1, 54.4 mm SL. All from Pará, Rio Tapajós basin.
LBP 24486, 10 of 16, 31.8-38.3 mm SL. LBP 24495, 16, 41-50 mm SL. LBP 24496, 39, 40-45 mm SL. All from Rondônia, Rio Madeira basin. MZUSP 90585, 5, 36.8-43.4 mm SL; Parnaíba, Rio Balsas. MZUSP 92288, 10 of 21, 67.3-39 mm SL. MZUSP 97276, 14, 30.2-35.5 mm SL; Amazonas, Rio Amazonas basin. MZUSP 97303, 5, 31.7-37.3 mm SL. MZUSP 97276, 14, 30.235.5 mm SL; Pará, Rio Tapajós basin. MZUSP 115653, 33, 31.1$45.3 \mathrm{~mm}$ SL; Mato Grosso, Rio Madeira basin. Guyana: ROM 64562, 10 of 62, 23.7-39.5 mm SL; Kurupukari, Rio Siparuni basin. Peru: MUSM 16020, 30, 26.8-48.6 mm SL. MUSM 47290, 40, 33.4-44.4 mm SL; Madre de Dios, Rio Madeira basin. Venezuela: ROM 94115, 10, 41-44.2 mm SL; San Fernando De Atabapo, Rio Orinoco basin. Poptella longipinnis: Brazil: INPA 2220, 3, 43.5-50.3 mm SL; Pará, Rio Tocantins-Araguaia basin. LBP 7792, 3, 33.6-37.7 mm SL; Mato Grosso, Rio TocantinsAraguaia basin. Suriname: MCP 11904, 2 of 3, 59.4-64.1 mm SL; Rio Corantijn. Venezuela: LBP 3060, 17, 34.8-42.3 mm SL; Bolivar, Rio Orinoco basin. Poptella paraguayensis: Brazil: LBP 3826, 15, 39.9-57.9 mm SL. LBP 5114, 11, 32.1-49.2 mm SL. LBP 9885, 10 of 20, 39-48,5 mm SL. All from Mato Grosso, Rio Paraguai basin. Poptella sp.: Brazil: INPA 12329, 4, 34.836.4 mm SL; Pará, Rio Tocantins basin. INPA 25677, 3, 31.6-46 mm SL; Pará, Rio Tocantins. INPA 52827, 20 of 55, 37.2-59.8 mm SL. LBP 16681, 51, 29.3-39.2, 4 c\&s, 32.6-38.9 mm SL. All from Pará, Rio Xingu basin. LBP 22676, 1, 57,1 mm SL; Tabatinga, Rio Amazonas basin. LBP 23782, 8, 36.9-47.6 mm SL; Acre, Rio Amazonas basin. LBP 8777, 36, 26.5-46.6, 5 c\&s, 43.1-34.6 mm SL; Goiás, Rio Araguaia basin. LBP 3980, 2, 38.240.2, 1, mm SL. LBP 7792, 55, 27.2-34.1, 3 c\&s, 32.8-30.7 mm SL. All from Mato Grosso, Rio Araguaia basin. MPEG 27210, 10, 29.1-39.3 mm SL, Pará, Rio Piriá. MZUSP 4822, 8 of 22, 36.2-43.4 mm SL. MZUSP 89385, 20 of 101, 36.1-49.1 mm SL. MZUSP 89289, 34, 21.2-41.1, 2 c\&s, 36.4-39.5 mm SL. All from Goiás, Rio Araguaia basin. Peru: MUSM 55050, 3, 64.4-79.5 mm SL. MUSM 55315, 2, 58.6-68.8 mm SL. All from Loreto, Rio Amazonas basin. Stethaprion erythrops: Peru: LBP 12583, 2, 43.1-47.1 mm SL; Nauta, Rio Marañon basin.

\section{Acknowledgments}

We thank Lúcia R. Py-Daniel (INPA), Aléssio Datovo (MZUSP), Claudio Oliveira (LBP) and Erling Holm (ROM) for curatorial assistance. We are grateful to Flávio A. Bockmann and André Esguícero (LIRP) for assistance with radiographs using the Faxitron LX60 DC12 (equipment acquired with support from FAPESP 09/54931-0). Willian M. Ohara provided the photo of the specimen in life and Laís Reia assisted with Fig. 5. This work received support from the CNPq Projects: "Revisão taxonômica da subfamília Stethaprioninae (Teleostei: Characiformes, Characidae)" (Proc. 140606/20157) and "Filogenia molecular dos peixes da subfamília Stethaprioninae (Teleostei: Characiformes: Characidae) usando elementos ultraconservados do genoma" (Proc. 153924/2018-7). RCB is financially supported by CNPq (Proc. 308784/2016-2). 


\section{References}

Bertaco VA, Lucinda PHF. Moenkhausia pankilopteryx, new species from rio Tocantins drainage, Brazil (Ostariophysi: Characiformes, Characidae). Zootaxa. 2006; 1120:57-68.

Bertaco VA, Malabarba LR, Hidalgo M, Ortega H. A new species of Hemibrycon (Teleostei: Characiformes: Characidae) from the río Ucayali drainage, Sierra del Divisor, Peru. Neotrop Ichthyol [serial on the Internet]. 2007; 5(3):251-57. Available from: http://dx.doi.org/10.1590/S1679-62252007000300003

Camelier P, Zanata AM. A new species of Astyanax Baird \& Girard (Characiformes: Characidae) from the Rio Paraguaçu basin, Chapada Diamantina, Bahia, Brazil, with comments on bony hooks on all fins. J Fish Biol [serial on the Internet]. 2014; 84(2):475-90. Available from: https://doi.org/10.1111/ jfb. 12295

Eigenmann CH. Fowler's "heterognathous fishes" with a note on the Stethaprioninae. Am Nat. 1907; 41(492):767-72.

Fink WL, Weitzman SH. The so-called Cheirodontin fishes of Central America with descriptions of two new species (Pisces: Characidae). Washington (DC): Smithsonian Institution Press; 1974. (Smithsonian Contributions to Zoology; No. 172).

Garcia-Ayala JR, Ohara WM, Pastana MNL, Benine RC. A new species of Brachychalcinus (Characiformes: Characidae) from the rio Xingu basin, Serra do Cachimbo, Brazil. Zootaxa [serial on the Internet]. 2017; 4362(4):564-74. Available from: https:// doi.org/10.11646/zootaxa.4362.4.5

International Union for Conservation of Nature (IUCN). Standards and Petitions Subcommittee. Guidelines for Using the IUCN Red List Categories and Criteria. Version 13 [Internet]. 2017 [updated 2017 Mar]. Available from: http://cmsdocs. s3.amazonaws.com/RedListGuidelines.pdf

Kullander SO. Three new cichlid species from southern Amazonia: Aequidens gerciliae, A. epae and A. michaeli. Ichthyol Explor Freshw. 1995; 6(2):149-70.

Mirande JM. Phylogeny of the family Characidae (Teleostei: Characiformes): from characters to taxonomy. Neotrop Ichthyol [serial on the Internet]. 2010; 8(3):385-568. Available from: http://dx.doi.org/10.1590/S1679-62252010000300001
Mirande JM. Morphology, Molecules and phylogeny of Characidae (Teleostei: Characiformes). Cladistics [serial on the Internet] 2018; 1-19. Available from: https://doi.org/10.1111/cla.12345

Ohara WM, Abrahão VP, Espíndola VC. Hyphessobrycon platyodus (Teleostei: Characiformes), a new species from the Rio Madeira basin, Brazil, with comments on how multicuspid teeth relate to feeding habits in Characidae. J Fish Biol [serial on the Internet]. 2017; 91(3):835-50. Available from: https:// doi.org/10.1111/jfb.13383

Pastana MNL, Ohara WM. A new species of Hyphessobrycon Durbin (Characiformes: Characidae) from rio Aripuanã, rio Madeira basin, Brazil. Zootaxa [serial on the Internet]. 2016; 4161(3):386-98. Available from: http://doi.org/10.11646/ zootaxa.4161.3.6

Reis RE. Systematic revision of the Neotropical characid subfamily Stethaprioninae (Pisces, Characiformes). Comum Mus Cienc Tecnol PUCRS Ser Zool. 1989; 2(6):3-86.

Reis RE. Subfamily Stethaprioninae (Silver dollar tetras). In: Reis RE, Kullander SO, Ferraris CJ, Jr., organizers. Check list of the freshwater fishes of South and Central America. Porto Alegre: Edipucrs; 2003. p.209-211.

Sidlauskas BL, Mol JH, Vari RP. Dealing with allometry in linear and geometric morphometrics: a taxonomic case study in the Leporinus cylindriformis group (Characiformes: Anostomidae) with description of a new species from Suriname. J Linn Soc London, Zool [serial on the Internet]. 2011; 162(1):10330. Available from: https://doi.org/10.1111/j.10963642.2010.00677.x

Taylor WR, Van Dyke GC. Revised procedures for staining and clearing small fishes and other vertebrates for bone and cartilage study. Cybium. 1985; 9(2):107-19. 